\title{
Integrated smart farming system in developing potential products of the village
}

\author{
A. Risdawati AP*, Cita Pertiwi, and Adelia Oktarina \\ Ministry of Villages, Development of Disadvantaged Regions, and Transmigration, Indonesia
}

\begin{abstract}
The village as an area that rests on local potential always needs development in product innovation and a sustainable market. In the world of agriculture, digital technology has been developing from nurseries to post-harvest. Included in the integrated agricultural system from upstream to downstream. Integrated smart farming system as an agricultural system that combines all components needed in agriculture (include the digitalization) were attracting young farmer's interest. This paper aims to describe an integrated agriculture model in Bali. The research was conducted by a descriptive analysis method of existing conditions. The results showed there was an upstream stage of agricultural development carried out through technology for seeding and breeding to produce more quality seedlings. The process involves young farmers who act as an organization that bridges farmers through funding for farmers, quality control, stock management, and farmer organizing. The downstream stage focuses on post-harvest processing, so farmers can sell their crops to market to meet retail and export needs. As the conclusion, the development of potential products through the use of the Integrated Smart Farming System can provide economic added value and encourage the economic growth of villages.
\end{abstract}

\section{Introduction}

Innovation in the world of agriculture continues to develop in every field. In developed countries, the agricultural industry has penetrated the use of modern technology where human involvement is getting less and less. Not limited to high technology, agricultural models have shifted to more integrated systems. Problems in the agricultural industry can be said to be divided into natural and non-natural constraints. Climate changes due to global warming that has an impact on the weather has a role in the success of the harvest. This is happening all over the world so farmers have to think about how to adapt to the increasingly uncertain weather. In addition to the weather, the upstream to downstream process are no fewer complex problems. The process from seedling to marketing goes through a long process and is often characterized by various obstacles. Returning to innovation in the world of agriculture, technical problems such as agricultural tools and weather can be handled with advanced technological innovations. However, downstream

* Corresponding author: andi.risdawati@kemendesa.go.id 
problems such as marketing, distribution and so on still depend on the system and social conditions.

Many countries are developing digital-based agriculture and getting success. Here as one of the countries that is developing a digital agricultural system, Russia has great potential for agricultural resources and interest in the development of a digital-based agricultural system is increasing. The Russian government through the Ministry of Agriculture provides a stimulus in the Samara region in the form of subsidies to farmers to buy precision agricultural equipment such as satellite navigation stations, computers, fertilizer sensors and so on [1]. Russia's development model is more about improving precision agricultural equipment. This supports an increase in the quantity and quality of agricultural products. In addition, there is the concept of integrated agriculture which is a combination of two or more agricultural fields based on the concept of the biological recycling. The development of an integrated agricultural system is important because it can overcome environmental problems and improve people's welfare. For example, in the research conducted by Mukhlis [2], the integrated agricultural development model solved the problem of fertilizers from agricultural and livestock waste.

Integrated farming systems are currently being developed and attracting interest from young farmers. The use of digital technology for agricultural activities are considered providing convenience and is a little cooler than conventional farming. The development of an integrated agricultural system cannot be separated from the upstream to downstream process that are packaged into a digital-based program using other applications or systems. In the process, the development of this integrated farming system utilizes some or even all technologies. Starting from capital for farmers, nurseries, harvesting, post-harvest production to marketing are packaged into a system. This can be a solution for agriculture in countries that have potential in agriculture. In Indonesia alone, there are several startups engaged in agriculture to develop this integrated farming system model. Call it TaniHub, BOS (Bali Organic Subak), MSMB and many more. It should be remembered that this kind of agricultural system development model is not easy to do in Indonesia. The lack of public knowledge, limited technology and willingness to develop are among the few obstacles faced.

Learning from the experiences that have been carried out by start-ups engaged in the development of digital-based agriculture, this study intends to describe the role of digital technology in developing agriculture. The potential of agriculture in Indonesia in various commodities and the large number of human resources of productive age are opportunities in developing digital agriculture. The limited knowledge and capabilities of human resources can certainly be overcome by learning, training and mentoring that can be carried out by the government, educational institutions, training institutions, CSR programs, as well as direct learning with parties who have succeeded in developing digital-based agriculture. Challenges and opportunities certainly need to be outlined as the basis for developing a digital based agricultural model to achieve smart farming.

\section{Literature review}

\subsection{Potential products of the village}

A superior commodity or product according to Setiyanto [3] is the result of agroecology in an area that can compete in the domestic market to the international market. Referring to this definition, it can be concluded that in a superior commodity or product there are advantages that make it unique and different so that it can compete in the market. One 
approach that can be used to identify whether a product is a superior product is the competitive advantage concept approach.

Competitive advantage is the value that arises beyond the cost of producing the product [4]. A product that has a competitive advantage can be judged from its position in the market, business model, or from processor competence in managing the product.

Christensen [5], based on these concepts, it can be concluded that a product can be assessed as a superior product that has a comparative advantage when it has added value, can compete in the market, and is managed properly. This shows that the superiority of a product does not only depend on the product itself but is also influenced by other factors outside the product such as human resources [6] and one of the management methods is technology [7].

Commodities or superior products with all the advantages they have are expected to be able to encourage regional economic growth, including villages. Prof. Dr. Ir. Soemarno, MS [8] in the study material for Agribusiness-Based Regional Development Strategy explained that superior products are the results of rural communities' efforts with the following criteria:

- Have high competitiveness in the market.

- Utilizing the potential of potential local resources so that they can be developed.

- Has high added value for rural communities.

- Economically profitable.

- Worth supporting capital.

\subsection{Production system}

The production system is an integrated system that has structural and functional components [9]. Structural and functional components of the production system were input, output, or other components involved in the production process itself. Like the production system in general, the agricultural production system can be defined as a production system that focuses on the agricultural sector.

Analysis of the production system will be very complex because it involves quite many factors that can affect the production process itself. Moreover, studying the production system cannot be done by just studying production itself, it is also necessary to study the concept of consumption because the demand that will affect production comes from consumer utilities that are not the same. This also applies to agricultural production systems derived from the production and consumption sectors [10].

\subsection{Integrated farming system}

Integrated Farming System (IFS) is an agricultural system that combines all components needed in agriculture to reduce residues and costs that arise during the process [11]. This system can be the alternative to monoculture farming systems and can solve the economic and ecological problems until it is known as an Integrated Biosystem [12, 13].

One example of the implementation of IFS is the value coalition model. The value coalitions model explains that product value comes from the interaction between support units in a workflow.

Smart farming uses an approach on how to process information related to agriculture and various fields in it for sustainable development. This approach is then reduced to various technological products that can be utilized by humans to support work in agriculture from upstream to downstream processes such as seeding, planting, monitoring, harvesting to maintain product quality. In several studies that have been carried out, the Internet of Things (IoT) was developed to increase the usability of various agricultural 
equipment and even create new agricultural technologies. This can be said as the adoption of technology into agriculture which can then create high-tech equipment and is expected to improve the quality and quantity of agriculture itself. In developing smart farming there is an architecture that adopts IoT which includes Wireless Sensor Networks (WSNs), meteorological stations and Unmanned Aerial Vehicles (UAVs). This component is an integrated process between machines and computing technology [14]. The most widely and popularly used system utilization today is Unmanned Aerial Vehicles (UAV) or what we know as drones that utilize RGB-D sensors. Through the developed algorithm, drones can be useful for example for ploughing the soil, fertilizing and others [15].

Smart farming does not only stop at developing information and communication technology in developing agriculture but also extends to big data [16]. This is important considering that until now the data collection related to agriculture is still not good and accurate. As a result, many policies are inadequate or even inappropriate because they do not have adequate agricultural data. If the policies implemented are not in accordance with the conditions of the community, of course it will be a challenge for the stakeholders. Big data that covers all components of agriculture such as land area, soil, climate, commodities, post-harvest processing and markets. Not infrequently this also has an impact on environmental damage and food security. Therefore, it is very necessary to do a lot of research on the development of digital-based agriculture without ignoring socio-political issues by using data and generating new data.

\section{Methods}

This study was conducted using a qualitative descriptive method. This method is used to be able to describe and explain well the practice of using digital technology in integrated agricultural processes $[17,18]$. The sample used in this study was selected purposively by taking into account the use of digital technology in agricultural activities that have been carried out by the sample. In this case, digital technology is expected to support agricultural activities as a whole from upstream to downstream. This study tries to explain the existing practice through the narrative of the research results.

\section{Results and discussion}

\subsection{Potential development of potential agricultural commodity products}

Bali is famous for its tourism sector as its superior product. Another potential sector is the tourism support sector, such as providing accommodation, food, and drink. However, since the Covid-19 pandemic, there has been a shift in the potential sectors in Bali, one of which is agriculture. According to the Head of Policy Analysis Division of the Bali Economics Bachelors Association (ISEI), as quoted in bali.bisnis.com [19], a number of regions in Bali experienced a shift in the potential sectors, namely agriculture, forestry, and fisheries. Therefore, it is necessary to harmonize the development of the agricultural sector as the main supporter of the leading tourism sector in Bali.

Based on BPS 2020 data, the horticulture sub-sector is one of the sub-sectors in the agricultural sector that has an important role in the development of the Bali Province. This can be seen from the value of the Gross Regional Domestic Product (GRDP) subcategory of seasonal, annual and other horticultural crops in Bali Province which continues to increase in line with the increasing value of GRDP from the categories of agriculture, forestry and fisheries. The occurrence of a pandemic, although it had quite an impact on various leading sectors, especially tourism, but agriculture, especially in the horticulture 
sub-sector, did not experience a significant decrease in production. One of the commodities in the horticulture subsector is annual fruit crops. Based on BPS data, the following are five fruit commodities with the most production in Bali Province in the 2017 - 2020 period.

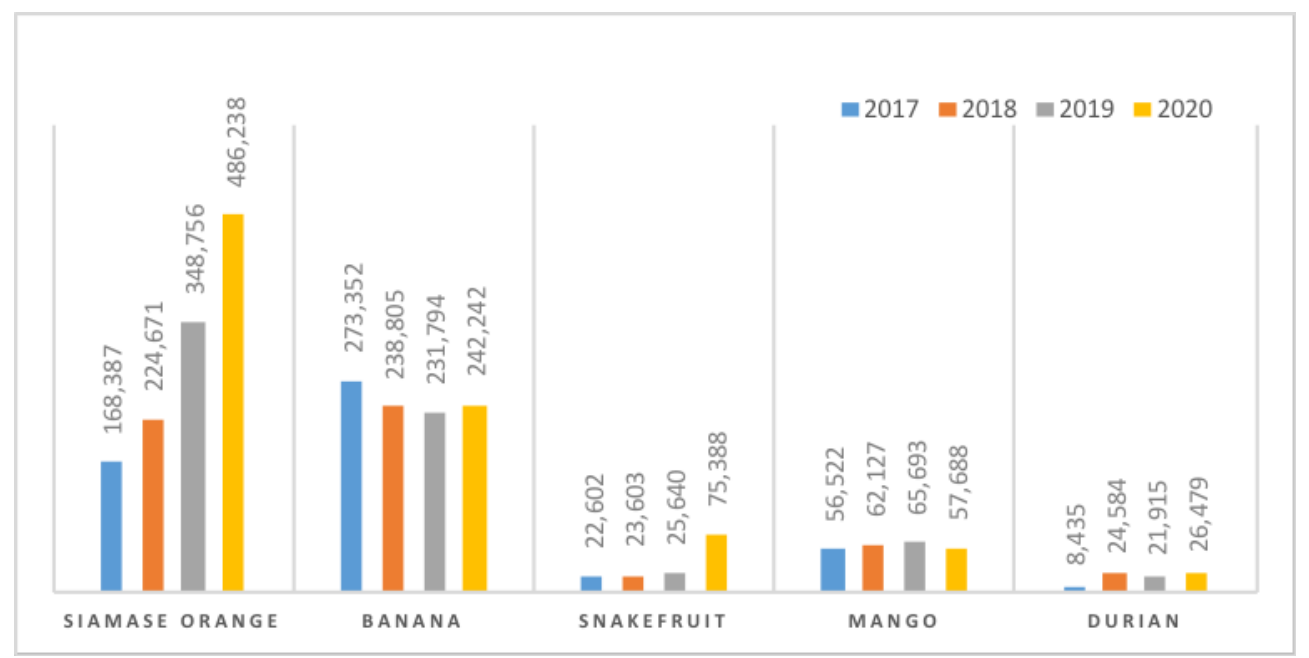

Fig. 1. Five fruit commodities with the most production period $2017-2020$ (tons).

Fruit crops have also become one of the main export commodities of the Province of Bali whose production did not experience much decline during the pandemic.

\subsection{Integrated smart farming system in Bali}

The innovation of the agricultural sector in Bali has been started since 2008 through the Integrated Agricultural System (Simantri) program. Simantri program aimed at encouraging an increase in the welfare of farmers, eradication of poverty and unemployment through the integration of activities of agriculture, plantation, animal husbandry and supporting sectors in order to develop the rural economy in a sustainable manner [20,21]. Along the way, the efforts made to develop agriculture in the village through Simantri activities illustrate the achievement of increasing agricultural productivity, as well as the realization of the welfare of farmers and rural communities.

Simantri, became the initial model to introduce rural communities to technology transfer in agriculture. Therefore, currently the adoption of an integrated farming system has developed a lot. Utilization of digital technology is carried out for agricultural development from upstream to downstream. Good practice in Bali in developing agriculture from upstream to downstream has been carried out by Bali Organic Subak (BOS) which has a sustainable business concept. Its scope of business is fertilization, breeding, agricultural development and agricultural technology. At this upstream stage, agricultural development is carried out through technology for seeding and nurseries so as to produce higher quality seeds. The second is the involvement of youth through the Keren Young Farmers Cooperative, which acts as an organization that bridges farmers through funding for farmers, quality control, stock management and farmer organizing. Third, BOS (Bali Organic Subak) which is engaged in post-harvest processing, agricultural events and festivals, retail Business to Business (B to B) and export, and apps development. In this business model, farmers can sell their harvests and then market them to meet retail and export needs. BOS also develops applications to support the marketing of superior village products. 
The concept developed by BOS involves young people who become farmers to be directly involved in village development. Given the need for agricultural development requires quite a lot of capital with the existence of cooperatives that involve non-farmers to support agriculture. Through this investment, farmers can get guaranteed funding and distribution of agricultural products.

BOS focused on selling agricultural products such as fruits and vegetables from farmers who have developed and used their fertilizer. BOS sells it to local retailers and online by apps and also exports it. BOS has exported mangosteen, dragon fruits and snakefruit to China. Based on data from the Agricultural Quarantine Agency, BOS was among the top 10 exporters of mangosteen in 2019.

The integration of agricultural systems with a business model similar to BOS has been widely developed by BOS. The concept is how to help farmers from upstream to downstream. Since the beginning of the nursery, processing raw agricultural products to become final products that have a higher selling value which can ultimately support economic growth in the village.

\section{Conclusion}

The development of potential products through the use of the Integrated Smart Farming System can provide economic added value and encourage the economic growth of villages. However, there are some challenges that remain to occur for program development, such as: (i) limited knowledge and ability of the community in utilizing digital technology for integrated agricultural development, (ii) increase product quantity continuously with quality consistency, and (iii) Bali, which exports a lot of fresh products such as fruits and fishery products, cannot meet market needs due to limited transportation during the pandemic.

Acknowledgement. The researchers would like to give appreciation to the Competitiveness Development Centre of Villages, Disadvantages Regions, and Transmigration, Ministry of Villages, Development of Disadvantages Regions, and Transmigration.

\section{References}

1. Shchutskaya, A. V., Afanaseva, E. P., \& Kapustina, L. V. Digital Farming Development in Russia: Regional Aspect. Coastal Research Library, 269-279. (2019)

2. Mukhlis, N. Melinda, Nofialdi \&Mahdi. (2018). International Journal of Sciences: Basic and Applied research (IJSBAR), 68-82 (2018)

3. A. Setiyanto, Pendekatan dan implementasi pengembangan kawasan komoditas unggulan pertanian, in Proceeding Forum Penelitian Agro Ekonomi, 31 (2). 171-195 (2003)

4. M.E. Porter, The competitive advantage: creating and sustaining superior performance, NY: Free Press (1985)

5. C.M. Christensen, MIT Sloan Management Review, 42(2), 105 (2001)

6. R. Hall, Strategic Management Journal, 14 (8), 607-618 (1993)

7. M.E. Porter, Technology and competitive advantage, The Journal of Business Strategy (1995)

8. S.M. Pasaribu, , Forum Penelitian Agro Ekonomi, 29 (1), 1-11 (2011)

9. V. Gaspersz, Ekonomi manajerial: Penerapan konsep-konsep ekonomi dalam manajemen bisnis total, Jakata: PT. Gramedia Pustaka Utama (1996)

10. R.E. Lopez, Western Journal of Agricultural Economics, 7 (2), 353-365 (1982)

11. G.L. Chan, Landscape Planning, 12 (3), 257-266 (1985) 
12. R.P. Soni, M. Katoch, R. Ladohia, IOSR Journal of Agriculture and Veterinary Science, 7 (10), 36-42 (2014)

13. S. Al Mamun, F. Nasrat, M.R. Debi, Journal of Environmental Science and Natural Resources, 4 (2011)

14. G. Kakamoukas, P. Sariciannidis, G. Livanos, M. Zervakis, D. Ramnalis, V. Polychronos, T. Karamitsou, A. Folinas, N. Tsitsiokas, A multi-collective, IoT-enabled, adaptive smart farming architecture, Proceeding of IEEE International Workshop on Imaging Systems and Techniques (IST). 1-6 (2019)

15. P. Tripicchio, M. Satler, G. Dabisias, E. Ruffaldi, C.A. Avizzano, Towards smart farming and sustainable agriculture with drones. Proceeding of International Conference on Smart Environments (pp. 140-143) (2015)

16. S. Wolfert, C. Ge, L. Verdouw, M.J. Bogaardt. Agricultural systems, 153, 69-80 (2017)

17. K. Caelli, L. Ray, J. Mill, International Journal of Qualitative Methods 2(2) 1-13 (2003)

18. W. Suardi, Ekubis, 2(1), (2017)

19. N.P. Eka Wiratmini, https://bali.bisnis.com/read/20210429/538/1388211/ada-pandemicovid-19-pertanian-jadi-sektor-unggulan-di-bali (2021)

20. I.S. Anugrah, S. Sarwoprasodjo, K. Suradisastra, N. Purnaningsih, Forum Penelitian Agro Ekonomi, 38, 157-176 (2014)

21. L.N. Hayati, I.K. Suratha, I.P. Ejournal Undiksha (2017) 